\title{
INFLUENCE OF ELECTRON IRRADIATION ON THE STRUCTURE EVOLUTION AND CREEP OF Zr1Nb ALLOY AT $380^{\circ} \mathrm{C}$
}

\author{
E.V. Karaseva ${ }^{1}$, S.V. Malykhin ${ }^{2}$, A.V. Mats ${ }^{1}$, V.A. Mats ${ }^{1}$, E.S. Savchuk ${ }^{1}$, V.I. Sokolenko ${ }^{1}$ \\ ${ }^{I}$ National Science Center "Kharkov Institute of Physics and Technology", Kharkiv, Ukraine \\ ${ }^{2}$ National Technical University "Kharkiv Polytechnic Institute”, Kharkiv, Ukraine \\ E-mail: vsokol@kipt.kharkov.ua
}

The effect of electron irradiation on the evolution of the structure and creep of the samples $\mathrm{Zr} 1 \mathrm{Nb}$ alloy of industrial production and samples obtained by the IPD method were studied. It was shown that irradiation with electrons with a dose not exceeding $D=5 \cdot 10^{19} \mathrm{~cm}^{-2}$ does not affect the plastic deformation mechanisms of the industrial $\mathrm{Zr} 1 \mathrm{Nb}$ alloy, as a result of which its high thermomechanical and radiation stability is maintained. Irradiation by electrons with an energy of $E=10 \mathrm{MeV}$ and doses of $D=6 \cdot 10^{17}$ and $5 \cdot 10^{19} \mathrm{~cm}^{-2}$ does not change the character of the deformation nanostructure of the $\mathrm{Zr} 1 \mathrm{Nb}$ alloy, but initiates return processes in grain boundaries and boundary regions and cause the changes in crystalline anisotropy of GPU lattice, which leads to softening of the material during creep at $380^{\circ} \mathrm{C}$.

\section{INTRODUCTION}

The need to create materials with the highest radiation resistance and providing the required life of the shells of heat-generating systems is one of the main tasks of reactor materials science. It is known that the degradation of the initial physical and mechanical properties of products and structures during irradiation is determined by changes in the composition and structure of materials $[1,2]$.

Now, the physical representations have been formed on the mechanisms of radiation damage to solids and two approaches have been chosen to create new reactor materials with the necessary physical and mechanical properties. The first approach is the new alloys and compounds to create, and the second is to change the properties of traditional materials by modifying the structure. The latter method is particularly interesting and promising in relation to zirconium and its alloys with niobium, which have a low effective neutron capture cross section, high thermomechanical and corrosion resistance, and good processability.

One of the promising methods for improving the performance characteristics of products made of zirconium alloys is the formation of nanocrystalline structures that have unique mechanical properties that are very different from the properties of coarse-grained polycrystalline materials.

Knowledge of the character and laws of transformation of the nanostructure under electron irradiation will allow us to conclude about the processes of microplastic flow, associate them with structural elements, and also analyze radiation-induced changes in mechanical properties from the point of view of the kinetics of dislocations.

In order to obtain the express information on the radiation resistance of constructional materials, electron accelerators are widely used. In the process of irradiation with a beam of charged particles, practically all known radiation effects and their physical nature can be reproduced and studied under well-controlled conditions. Simulation experiments along with reactor tests make a significant contribution to the study of radiation physics and the development of radiation technologies, as well as to solving the problems of creating new materials with high radiation resistance $[3,4]$.

When assessing and choosing materials in reactor construction, much attention is paid to the study of creep characteristics, as well as their change under the influence of irradiation, temperature, and mechanical loads, since most industrial constructions operate under static loading conditions.

The imposition of tensile stresses leads to a sharp removal of the previously created deformation structure from the metastable state, and to the formation of a new structure adapting to uniaxial loading. Under creep conditions, when the rate of plastic relaxation prevails over the rate of plastic deformation, the main contribution to the development of plastic deformation is made by stress relaxation mechanisms $[5,6]$.

The purpose of this work is to investigate the effect of electron irradiation on the creep characters and the structure evolution of samples of the industrial $\mathrm{Zr} 1 \mathrm{Nb}$ alloy and the samples of $\mathrm{Zr} 1 \mathrm{Nb}$ alloy obtained using IPD.

\section{MATERIAL AND PROCESSING METHOD}

It was investigated the samples of $\mathrm{Zr} 1 \mathrm{Nb}$ alloy after industrial processing and the samples of $\mathrm{Zr} 1 \mathrm{Nb}$ alloy obtained by electron beam melting. In order to study the effect of electron irradiation on the structure and properties of the obtained samples, the following processing modes were studied:

1. MT-1 - industrial processing.

2. MT 2 -industrial processing + electron irradiation with an energy of $E=10 \mathrm{MeV}$ and a dose of $D=5 \cdot 10^{19} \mathrm{~cm}^{-2}$

3. MT-3 - combined rolling at $77 \ldots 300 \mathrm{~K}$, strain $(\varepsilon)$ was $\varepsilon=3.9$.

4. MT-4 - MT-3 + electron irradiation with an energy of $E=10 \mathrm{MeV}$ and dose of $D=6 \cdot 10^{17} \mathrm{~cm}^{-2}$.

5. MT-5 - MT-3 + electron irradiation with an energy of $E=10 \mathrm{MeV}$ and dose of $D=5 \cdot 10^{19} \mathrm{~cm}^{-2}$. 
The samples of the $\mathrm{Zr} 1 \mathrm{Nb}$ industrial alloy in the form of plates, cut by the electron-spark method from the wall of channel pipe, had dimensions of $3 \times 0.3 \times 60 \mathrm{~mm}$ the same as the samples obtained by rolling. The axis of tension of the samples under creep was oriented along the rolling direction.

The samples were irradiated an electron beam with the energy of $E=10 \mathrm{MeV}$ at a temperature not exceeding $90^{\circ} \mathrm{C}$ with the doses of $D=6 \cdot 10^{17}$ and $5 \cdot 10^{19} \mathrm{~cm}^{-2}$. The accelerated electron flow was formed by a linear electron accelerator operating in a pulsed mode. The average beam current was $10 \mu \mathrm{A}$, the pulse duration was $3.6 \mu \mathrm{s}$, the transmission frequency was $6 \mathrm{~Hz}$. The temperature of the samples was determined on the temperature dependence of the electrical resistance of the $\mathrm{Zr} 1 \mathrm{Nb}$ alloy.

The creep tests were carried out in the step loading regime at $380{ }^{\circ} \mathrm{C}$ that corresponds to the reactor operating temperature, the measurement accuracy was $5 \cdot 10^{-5} \mathrm{~cm}$. The structure evolution control was carried out using the electron microscopic method.

$\mathrm{X}$-ray studies of $\mathrm{Zr} 1 \mathrm{Nb}$ alloy samples were carried out on a DRON-2.0 general-purpose X-ray diffractometer in filtered $(\mathrm{Ni})$ radiation from the copper anode of the 1.2 BSV-22 tube at the voltage of $U=30 \mathrm{kV}$ and the current of $I=20 \mathrm{~mA}$.

\section{RESULTS AND DISCUSSION}

Fig. 1 shows the dependences of the creep rate on the true stress value at $380{ }^{\circ} \mathrm{C}$ for samples of the $\mathrm{Zr} 1 \mathrm{Nb}$ alloy in various structural states, the character of which conditioned by different mechanisms of plastic flow.

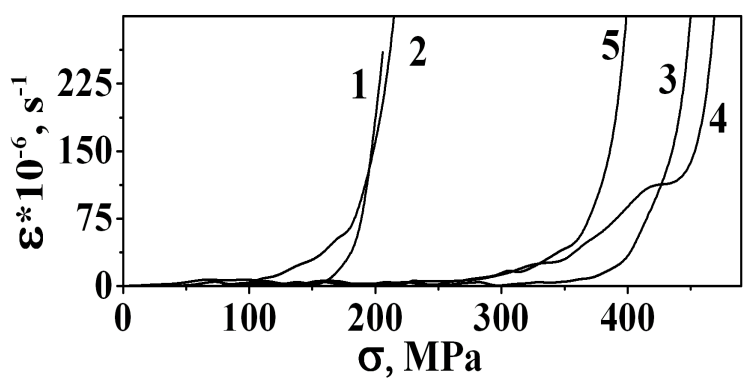

Fig. 1. Creep rates at $T=380^{\circ} \mathrm{C}$ as a function of the true stress for the samples of Zr1Nb alloy subjected to different treatments: $1-M T-1 ; 2-M T-2 ; 3-M T-3$;

$$
4-M T-4 ; 5-M T-5
$$

The processes of plastic deformation in $\mathrm{Zr} 1 \mathrm{Nb}$ alloy samples of industrial processing, as well as the nature of hardening of them, controlled by strain hardening mechanism, i.e. are determined by the resistance to movement dislocations by impurities, by "forest" dislocations and by deformation defects [5]. A large number of finely dispersed phase precipitates inside the grains and at the its boundaries and complicates the intragranular sliding and the exit of dislocations to the boundaries. A dynamic return in such structure is due to the formation of throw lines, fragmentation, and rotation of the grains.

Irradiation by electrons with an energy of $E=10 \mathrm{MeV}$ and a dose of $D=5 \cdot 10^{19} \mathrm{~cm}^{-2}$ of $\mathrm{Zr} 1 \mathrm{Nb}$ alloy samples of industrial processing leads to the decrease in the yield strength and an increase in the creep rate at the initial stage of the plastic flow, which indicates softening of the material due to the irradiation. But with the increasing of the stress the creep rate decreases, i.e. the development of the process of plastic deformation under creep of irradiated samples is also controlled by hardening mechanisms.

Structural studies showed that the microstructure of the finished tubes of $\mathrm{Zr} 1 \mathrm{Nb}$ alloy is represented by equiaxed grains of the $\alpha$ phase with an average size of $5 \mu \mathrm{m}$, which are unevenly filled with dislocations with density of $5 \cdot 10^{10} \mathrm{~cm}^{-2}$ and a dispersed particles of $\beta$-niobium phase with a size of $40 \mathrm{~nm}$, which uniformly distributed in them and along the grain boundaries (Fig. 2,a). X-ray analysis revealed the presence of a rather strong texture in the metal of the finished tubes, which is parallel to the basal plane of zirconium crystals tangent to the surface of the tubes.
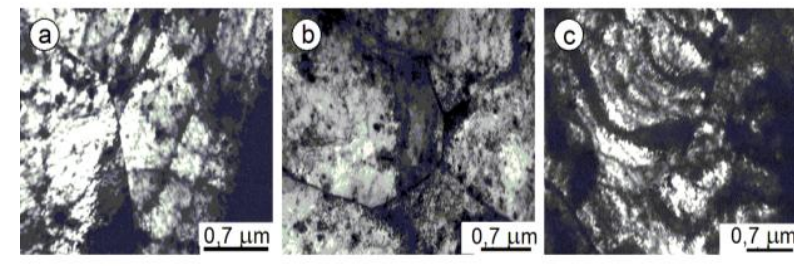

Fig. 2. TEM images of ZrlNb alloy after follows treatments: $a-M T-1 ; b-M T-2$;

$c-$ MT- $2+$ creep at $380{ }^{\circ} \mathrm{C}\left(\sigma \approx 0.9 \sigma_{B}\right)$

Electron irradiation with a dose of $D=5 \cdot 10^{19} \mathrm{~cm}^{-2}$ leads to the annihilation of the initial dislocations and a significant decrease in their density, as well as to the formation of small dislocation loops of vacancy origin (see Fig. 2,b).

During the creep, slip processes actively develop due to the low level of internal stresses. This leads to the formation of dense extended dislocation clusters, causing smooth turns of the microvolumes of the lattice and the adapting of new slip systems to the direction of the applied external stresses (see Fig. 2,c), which can cause an increase in the tensile strength.

Thus, the nature of the obtained dependences is in good agreement with the ideas of the thermoactivation model of plastic deformation and indicates a rather high thermomechanical and radiation stability of the $\mathrm{Zr} 1 \mathrm{Nb}$ industrial alloy.

The nanostructure of the $\mathrm{Zr} 1 \mathrm{Nb}$ alloy with a nanograin size of $\sim 60 \mathrm{~nm}$ was obtained by the combined rolling method at $77 \ldots 300 \mathrm{~K}$. Analysis of the results of structural studies of deformed samples suggests that large degrees of rolling lead to the formation of nanograin structure that is homogeneous in volume of the material (Fig. 3, curve 1) and after electron irradiation the nanostructured state of the lattice was preserved (see Fig. 3, curve 2).

It was shown in works [7-9] that the process of plastic deformation of nanostructured materials is caused by the simultaneous action of several mechanisms: intragranular sliding, creep over of dislocations along the boundaries, the slip on the grain boundaries, and rearrangement of the boundaries structure. These processes are responsible for high yield and strength limits, low strain hardening and plasticity, as well as the high degree of strain localization. 


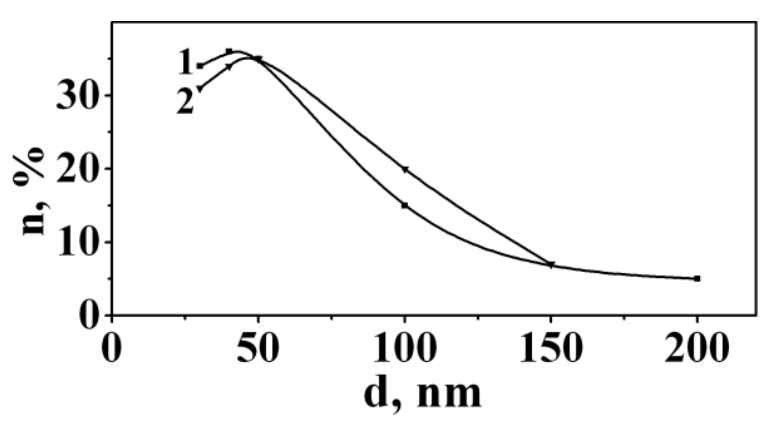

Fig. 3. Spectra of grain size distribution in the samples of nanostructured Zr1Nb alloy subjected to the MT-3 (1) and MT-5 (2) treatments

Irradiation by electrons of the nanostructured $\mathrm{Zr} 1 \mathrm{Nb}$ alloy leads to the softening (see Fig. 1, curves 4, 5), the yield strength decreases by $\sim 15 \%$ and plasticity increases by $\sim 40 \%$ compared with the rolled state. Moreover, an increase in the radiation dose by more than two orders of magnitude leads to an increase in softening processes: the yield strength varies slightly, but the creep rate increases and the tensile strength decreases by $\sim 15 \%$.

It is known [1] that interstitial atoms and vacancies arising under the action of irradiation are either located close to each other and easily recombine with the complete abolition of the radiation effect, or are removed from each other at considerable distances and the connections between them are lost. In the case under consideration, the migration of free defects from the formation sites to the sinks (dislocations and interfaces) hase the diffusion character, directed and accelerated by the action of elastic fields. At that, the probability of defects exit to the boundaries sharply increases, although the efficiency of defects adsorption by dislocations is also high, as evidenced by a decrease in their density.

A decrease in the starting stress of dislocation motion indicates relaxation processes that have occurred in the nanostructure as a result of irradiation. The relaxation of internal stresses in the volume of the material is due to the formation of a large number of vacancies, which stimulates non-conservative slip of dislocations, initiates the return processes at grain boundaries and in the boundaries regions, for example, the creep over and the annihilation of dislocations due to their interaction with vacancies of radiation origin, which leads to the formation of a more equilibrium boundaries structure.

The formation of the relaxed state due to irradiation is connected with the fact that in the elastically stressed nanostructure created by cold rolling, the activation energy of the return processes sharply decreases, the number of local plastic flow sites increases. High internal stresses in a strongly deformed matrix cause a high speed of polygon-type rearrangement. This is probably due to the fact that the contribution to the transformation of the matrix and boundary structure of processes such as transverse and conservative slip of dislocations competes with the creep over of the edge components of dislocations [1].

The decrease in the lattice defectiveness and the level of internal stresses leads to the change in the mechanical characteristics during subsequent tests under creep conditions.

On the curve of the creep rate dependence on stress (see curve 4, Fig. 1) of nanostructured $\mathrm{Zr} 1 \mathrm{Nb}$ alloy samples after irradiation with a dose of $D=6 \cdot 10^{17} \mathrm{~cm}^{-2}$, the stair is observed, which indicates a change in the mechanism of the deformation during creep. At the first the return processes at the grain boundaries develop, and then the sliping on the boundaries and the restructuring of the structure begin.

After irradiation with a dose of $D=5 \cdot 10^{19} \mathrm{~cm}^{-2}$, part of the return processes and the reconstruction of the boundaries structure probably occur during the irradiation and the plastic deformation process under the conditions of creep of already relaxed material begins immediately with sliping on the boundaries and restructuring the boundaries structure.

Structural studies showed that due to irradiation of a nanostructured alloy with a dose of $D=6 \cdot 10^{17} \mathrm{~cm}^{-2}$, the density of free dislocations decreased to $3.3 \cdot 10^{10} \mathrm{~cm}^{-2}$ and the nature of their distribution has changed, the level of internal stresses has decreased. At the same time, the volume concentration of boundaries increased due to the formation of small-angle boundaries of the polygonal type (Fig. 4,b).

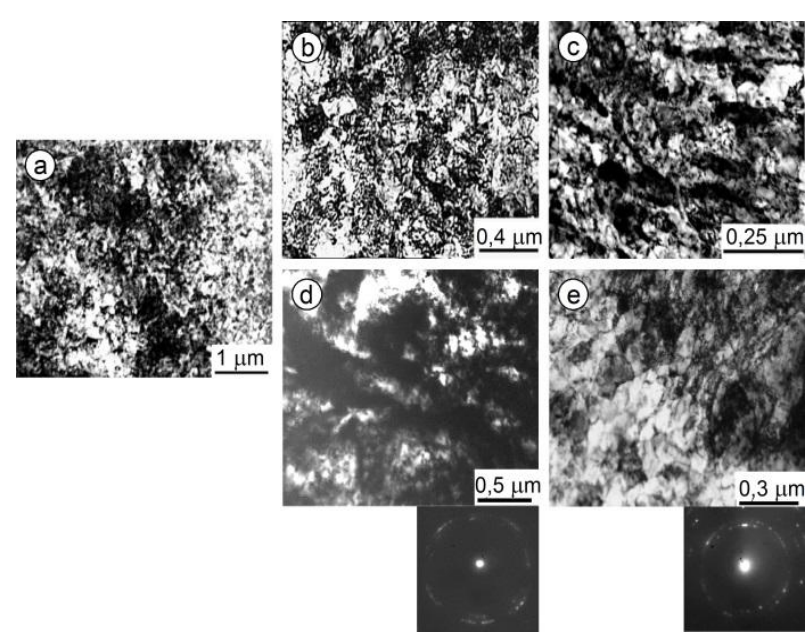

Fig. 4. TEM images of ZrlNb alloy after follows treatments: $a-M T-3 ; b-M T-4 ; c-M T-4+$ creep at $380{ }^{\circ} \mathrm{C}\left(\sigma \approx 0.9 \sigma_{B}\right) ; d-M T-5 ; e-M T-5+$ creep at $380{ }^{\circ} \mathrm{C}\left(\sigma \approx 0.9 \sigma_{B}\right)$

In the process of creep at $380{ }^{\circ} \mathrm{C}$, the nanostructured state, which extant after irradiation with a dose of $D=6 \cdot 10^{17} \mathrm{~cm}^{-2}$, becomes unstable, intensive restructuring begins, the process of recrystallization develops, and new grains $\sim 160 \mathrm{~nm}$ in size are formed. Moreover, the spread in grain size is $36 \ldots 160 \mathrm{~nm}$. The region of uniform deformation ends with the formation of dislocation boundaries extended along the direction of extension (see Fig. 4,c).

Increasing the dose to $D=5 \cdot 10^{19} \mathrm{~cm}^{-2}$ leads to the distruction of part of the dislocation boundaries. Herewith the distance between the high-angle boundaries $(<100 \mathrm{~nm})$ is maintained and the areas between them are filling with dislocations (see Fig. 4,d).

In the creep process of samples irradiated with a dose of $D=5 \cdot 10^{19} \mathrm{~cm}^{-2}$, an intensive transformation of 
the structure occurs through dynamic recrystallization, i.e. the nanostructure becomes unstable. Distruction and reconstruction, of the boundaries leads to an increase in the degree of distortion of the lattice and the heterogeneity of stresses. The size of recrystallized grains varies over a wide range of $40 \ldots 300 \mathrm{~nm}$, but the highest concentration is the grains of $70 \ldots 80 \mathrm{~nm}$ size (see Fig. 4,e). Thus, with an increase in the radiation dose, the instability of the nanostructure in the process of subsequent deformation at $380{ }^{\circ} \mathrm{C}$ increases.

The results of X-ray diffraction studies in the BraggBrentano focusing geometry of nanostructured $\mathrm{Zr} 1 \mathrm{Nb}$ alloy samples indicate the formation of the rolling texture when the reflecting basal planes of the HCP lattices are oriented mainly parallel to the surface plane. To estimate the size of the CSR and the level of microstrains, the approximation method was used. Quantitative values of the CSR (L) and microstrains ( $(\varepsilon)$ are given in Table.

Values of CSR (L), microstrains ( $(\varepsilon)$, periods a and $\mathbf{c}$ and $\mathbf{c / a}$ ratios in the nanostructured $\mathrm{Zr} 1 \mathrm{Nb}$ alloy

\begin{tabular}{|c|c|c|c|c|c|}
\hline $\begin{array}{c}\text { Modes of } \\
\text { treatment }\end{array}$ & $\mathbf{a}, \AA$ & $\mathbf{c}, \AA$ & $\mathbf{c} / \mathbf{a}$ & $\begin{array}{c}\mathbf{L}, \\
\text { HM }\end{array}$ & $\begin{array}{c}\boldsymbol{\varepsilon}, \\
10^{-3}\end{array}$ \\
\hline MT-3 & 3.2418 & 5.1461 & 1.5874 & 55.1 & 4.21 \\
\hline MT-5 & 3.2384 & 5.1469 & 1.5893 & 46.7 & 2.98 \\
\hline
\end{tabular}

It is seen that the level of microstrains decreases by about $30 \%$ and the CSR sizes also noticeably decrease as a result of irradiation

In addition to estimating the CSR and microstrains, the study of the effect of electron irradiation on the values of the periods of the hexagonal lattice $\mathbf{a}$ and $\mathbf{c}$ in the $\mathrm{Zr} 1 \mathrm{Nb}$ nanostructured alloy is of undoubted interest. The periods were calculated according to the position of the diffraction maxima (00.6) and (21.3).

Irradiation of the $\mathrm{Zr} 1 \mathrm{Nb}$ alloy by electrons with an energy of $10 \mathrm{MeV}$ leads to a noticeable decrease in the period $\mathbf{a}$ in the basal plane of the hexagonal lattice $\Delta \mathbf{a} / \mathbf{a}=-(0.5 \ldots 1.0) \cdot 10^{-3}$ (see Table). In this case, the period $\mathbf{c}$ increases and amounts to $\Delta \mathbf{c} / \mathbf{c}=(1.5 \ldots 2.6) \cdot 10^{-4}$. This may indicate the distribution of point defects in the prismatic plane.

Thus, the features of the change in the mechanical properties of the $\mathrm{Zr} 1 \mathrm{Nb}$ alloy after irradiation are also associated with changes in the crystal anisotropy of the HCP lattice.

The data of electron microscopy and X-ray structural studies indicate the occurrence of relaxation processes under the action of irradiation in a nanostructure of strain origin, which leads to the transformation of the structure during subsequent deformation under creep conditions at $380{ }^{\circ} \mathrm{C}$ and to the softening of the material.

\section{CONCLUSIONS}

The effect of electron irradiation on the creep and structure evolution of the $\mathrm{Zr} 1 \mathrm{Nb}$ alloy of industrial production and obtained by the IPD method was studied.
It was shown that irradiation by electrons with an energy of $E=10 \mathrm{MeV}$ and a dose not exceeding $D=$ $5 \cdot 10^{19} \mathrm{~cm}^{-2}$ initiates dislocation rearrangements in the samples of the $\mathrm{Zr} 1 \mathrm{Nb}$ industrial alloy, but will not affect the mechanism of plastic flow of the material. The process of plastic deformation is controlled by the mechanism of strain hardening, as a result of which the high thermomechanical and radiation stability of the alloy is maintained.

Irradiation by electrons with an energy of $E=10 \mathrm{MeV}$ and a the dose of $D=10^{17}$ and $6 \cdot 10^{17} \mathrm{~cm}^{-2}$ initiates structural transformations, but does not destroy the nanostructured state of the $\mathrm{Zr} 1 \mathrm{Nb}$ alloy.

The softening of the irradiated $\mathrm{Zr} 1 \mathrm{Nb}$ alloy during creep is due to relaxation of internal stresses by activation of return processes in the boundaries regions, exit of dislocations to the boundaries, rearrangement of the boundaries structure, development of recrystallization processes, as well as changes in the crystal anisotropy of the GPU lattice. Moreover, with an increase in the radiation dose, the instability of the nanostructure in the process of deformation at $380{ }^{\circ} \mathrm{C}$ increases.

\section{REFERENCES}

1. V.N. Voyevodin, I.M. Neklyudov. Evolution of structure phase state and radiation resistance of structural materials. Kiev: "Naukova Dumka", 2006, p. 376.

2. D.L. Douglass. The metallurgy of zirconium. M.: "Atomizdat", 1975, p. 360.

3. R.Z. Valiev, I.V. Aleksandrov. Nanostructure materials got an intensive plastic deformation. M.: "Logos", 2000, p. 271.

4. V.V. Rybin. Large plastic deformation and fracture of metals. M.: "Metallurgy Publ.", 1986, p. 224.

5. E.V. Karaseva, V.I. Sokolenko, Ya.D. Starodubov, T.A. Dergach. Mechanical properties and creep of samples from TVEL cladding tubes of $\mathrm{Zr} 1 \mathrm{Nb}$ alloy in the temperature range of $77 \ldots 650 \mathrm{~K} / /$ Problems of Atomic Science and Technology. Series "Physics of Radiation Effect and Radiation Materials Science". 2005, N 3, p. 94-98.

6. E.V. Karaseva, D.G. Malyikhin, A.V. Matz, V.I. Sokolenko. Creep of the $\mathrm{Zr} 1 \mathrm{Nb}$ alloy in various structural states in the temperature range $300 \ldots 700 \mathrm{~K} / /$ Problems of Atomic Science and Technology. Series "Physics of Radiation Effect and Radiation Materials Science" (98). 2011, N 4(74), p. 45-48.

7. E.V. Karaseva, A.V. Matz, V.I. Sokolenko, V.A. Frolov. Effect of structural instability on creep of zirconium, which subjected to intense plastic deformation // Problems of Atomic Science and Technology. Series "Vacuum, Pure Materials, Superconductors" (20). 2014, N 1(89), p. 106-109.

8. E.V. Karaseva. Influence of structural instability at the creep characteristics of constructing materials // Problems of Atomic Science and Technology. Series "Physics of Radiation Effect and Radiation Materials Science" (106). 2015, N 5(99), p. 130-133.

9. V.I. Sokolenko, E.V. Karaseva, A.V. Mats, E.S. Savchuk, V.A. Frolov. Peculiarities of stress 
relaxation of nanostructured alloy $\mathrm{Zr} 1 \mathrm{Nb}$ after various influences // Problems of Atomic Science and
Technology. Series "Physics of Radiation Effect and Radiation Materials Science”. 2017, N 4, p. 79-83.

Статья поступила в редакциию 20.07.2020 2.

\title{
ВЛИЯНИЕ ЭЛЕКТРОННОГО ОБЛУЧЕНИЯ НА ЭВОЛЮЦИЮ СТРУКТУРЫ И ПОЛЗУЧЕСТЬ СПЛАВА $\mathrm{Zr} 1 \mathrm{Nb}$ ПРИ $380{ }^{\circ} \mathrm{C}$
}

\author{
Е.В. Карасева, С.В. Малыхин, А.В. Мац, В.А. Мац, Е.С. Савчук, В.И. Соколенко
}

Изучено влияние электронного облучения на эволюцию структуры и ползучесть сплава Zr1Nb промышленного производства и полученного методом ИПД. Показано, что облучение электронами с дозой, не превышающей $D=5 \cdot 10^{19} \mathrm{~cm}^{-2}$, не влияет на механизмы пластической деформации промышленного сплава $\mathrm{Zr} 1 \mathrm{Nb}$, вследствие чего сохраняется его высокая термомеханическая и радиационная устойчивость. Облучение электронами с энергией $E=10 \mathrm{MэB} \mathrm{и} \mathrm{дозами} D=6 \cdot 10^{17}$ и $5 \cdot 10^{19} \mathrm{~cm}^{-2}$ не изменяет характер деформационной наноструктуры сплава $\mathrm{Zr} 1 \mathrm{Nb}$, но инициирует возвратные процессы в границах зерен и приграничных областях, вызывает изменения кристаллической анизотропии ГПУ-решетки, что приводит к разупрочнению материала в процессе ползучести при $380^{\circ} \mathrm{C}$.

\section{ВПЛИВ ЕЛЕКТРОННОГО ОПРОМІНЕННЯ НА ЕВОЛЮЦЮ НАНОСТРУКТУРИ ТА ПОВЗУЧІСТЬ СПЛАВУ Zr1Nb ПРИ $380{ }^{\circ} \mathrm{C}$}

\author{
С.В. Карасьова, С.В. Малихін, О.В. Мац, В.О. Мац, С.С. Савчук, В.І. Соколенко
}

Вивчено вплив електронного опромінення на еволюцію структури та повзучість сплаву Zr1Nb промислового виробництва і отриманого методом ІПД. Показано, що опромінення електронами 3 дозою, яка не перевищує $D=5 \cdot 10^{19} \mathrm{~cm}^{-2}$, не впливає на механізми пластичної деформації промислового сплаву Zr1Nb, внаслідок чого зберігається його висока термомеханічна та радіаційна стійкість. Опромінення електронами 3 енергією $E=10 \mathrm{MeB}$ і дозами $D=6 \cdot 10^{17}$ i $5 \cdot 10^{19} \mathrm{~cm}^{-2}$ не змінює характер деформаційної наноструктури сплаву $\mathrm{Zr} 1 \mathrm{Nb}$, але ініціює зворотні процеси в межах зерен і приграничних областях, викликає зміни кристалічної анізотропії ГПУ-гратки, що призводить до знеміцнення матеріалу в процесі повзучості при $380^{\circ} \mathrm{C}$. 